\title{
Apoplastic Peroxidase Generates Superoxide Anions in Cells of Cotton Cotyledons Undergoing the Hypersensitive Reaction to Xanthomonas campestris pv. malvacearum Race 18
}

\author{
C. Martinez, ${ }^{1}$ J. L. Montillet, ${ }^{2}$ E. Bresson, ${ }^{1}$ J. P. Agnel, ${ }^{2}$ G. H. Dai, ${ }^{1}$ J. F. Daniel, ${ }^{1}$ J. P. Geiger, ${ }^{1}$ \\ and M. Nicole ${ }^{1}$ \\ ${ }^{1}$ ORSTOM, Genetrop, Plant Pathology Department, BP 5045, 34032 Montpellier, France; ${ }^{2}$ CEA, Départe- \\ ment d'Ecophysiologie Végétale et de Microbiologie, Cadarache, 13108 Saint-Paul-Lez Durance, France \\ Accepted 26 July 1998.
}

Cotton cotyledons displayed a hypersensitive reaction (HR) in the resistant cultivar Reba B50 after infiltration with the avirulent race 18 of Xanthomonas campestris pv. malvacearum $(\mathrm{Xcm})$. Generation of active oxygen species during the HR was studied biochemically and cytochemically. $\mathrm{O}_{2}{ }^{-}$was detected in cotyledon disks by the cytochrome c reduction assay $3 \mathrm{~h}$ after inoculation. This activity was inhibited by superoxide dismutase (SOD) and by the peroxidase inhibitors salicylhydroxamic acid (SHAM) and KCN but not by the NADPH oxidase inhibitor diphenyleneiodonium chloride (DPI). Strong NADH oxidation activity also was found $3 \mathrm{~h}$ after inoculation in crude extracts or in apoplastic washing fluid and was dramatically decreased after treatment with SHAM or KCN. NADH oxidation was activated by 2,4dichlorophenol and $\mathrm{MnCl}_{2}$, indicating the involvement of a peroxidase. Activity of cationic peroxidase isoforms (pI 9 to 9.5) constitutively expressed in cotyledons was found to be enhanced $3 \mathrm{~h}$ after inoculation in the resistant cultivar. Activities of apoplastic peroxidase(s) and $\mathrm{H}_{2} \mathrm{O}_{2}$ accumulation were observed cytochemically, 3 and $4 \mathrm{~h}$ post inoculation, respectively. When digitonin, a $\mathrm{O}_{2}{ }^{-}$elicitor, was infiltrated into cotyledons of resistant and susceptible cultivars, generation of $\mathrm{O}_{2}{ }^{-}$radicals was shown to be reduced by SOD and inhibited by SHAM and KCN as observed after infection, and also by DPI. Our results strongly suggest that cotton cotyledons contain two $\mathrm{O}_{2}{ }^{--}-$ generating systems and that cells undergoing the HR in response to an avirulent race of $\mathrm{Xcm}$ produce $\mathrm{O}_{2}{ }^{--}$through the activation of an apoplastic peroxidase.

Among the early events that take place during plantpathogen interactions, the oxidative burst consisting of a localized, rapid, and transient production of active oxygen species (AOS) has received considerable attention for its role in

Corresponding author: M. Nicole; Telephone: 33 (0) 4674162 91; Fax: 33 (0) 4674162 83; E-mail: nicole@mpl.orstom.fr

C. Martinez and J. L. Montillet contributed equally to this work. plant resistance (Sutherland 1991; Medhy 1994; Baker and Orlandi 1995; Bolwell and Wojtaszeck 1997; Lamb and Dixon 1997; Wojtaszeck 1997). It has been postulated that highly reactive oxygen intermediates $\left(\mathrm{O}_{2} \cdot^{-}, \mathrm{H}_{2} \mathrm{O}_{2}, \mathrm{OH} \cdot\right)$ could initiate lipid peroxidation of the plant plasma membrane leading at the site of infection to (i) increase cell leakage and hypersensitive cell death, and (ii) release of signal molecules that would be involved in the activation of defense genes in more distant cells (Low and Merida 1996; Anderson et al. 1998). Moreover, cross-linking of cell wall proteins and phenol monomers associated with plant defense has been shown to be promoted by AOS (Tenhaken et al. 1995; Milosevic and Sluzarenko 1996; Ogawa et al. 1997). Hydrogen peroxide, produced by challenged cells, has also been demonstrated to act as a diffusible signal for the induction of genes encoding glutathione-S-transferase and glutathione peroxidase in surrounding cells that might protect those cells from the oxidative damage (Levine et al. 1994). More recently, in parsley cells challenged with the oligopeptide elicitor Pep-13, it has been demonstrated that among AOS produced during the oxidative burst only $\mathrm{O}_{2} \cdot{ }^{-}$was an essential element of the signal cascade leading to phytoalexin production (Jabs et al. 1997). Finally, the oxidative burst may also function as a first line of defense in resistant plants, being directly toxic to the pathogen during the earliest stages of infection (Baker and Orlandi 1995).

Studies on enzymatic machineries that produce the oxidative burst in plants have mainly focused on the NADPH oxidase complex (Levine et al. 1994; Desikan et al. 1996; Doke et al. 1996), which is also known to be the primary source of AOS production in mammal neutrophils (Segal and Abo 1993). Although the NADPH complex has not been purified so far from plant cells, Groom et al. (1996) and Keller et al. (1998) recently presented evidence that in rice and Arabidopsis thaliana homologs exist of the neutrophil NADPH oxidase gp91phox subunit gene. This gene encodes a plasma membrane protein containing two putative $\mathrm{Ca}^{2+}$ binding domains and one $\mathrm{G}$ protein regulating region (Keller et al. 1998). Several other results from pharmacological, immunological, and reconstitution experiments further strengthen the idea that a complex similar to that found in the mammalian neutrophil is present in plants and regulated via comparable mechanisms 
(Levine et al. 1994; Doke and Miura 1995; Auh and Murphy 1995; Desikan et al. 1996; Dwyer et al. 1995; Simon-Plas et al. 1997). It has also been proposed that certain peroxidases, acting as NAD(P)H oxidases (Halliwell 1978), could be alternative sources of AOS in plants challenged by pathogens (Bolwell et al. 1995) or elicitors (Lindner et al. 1988). Moreover, changes in the activities of enzymes potentially involved in the regulation of AOS accumulation have been shown in hypersensitively reacting bean leaves (Adam et al. 1995). In particular, the activity of several peroxidase isoforms was shown to increase during an incompatible interaction within inoculated and surrounding tissues.

Infiltration of avirulent races of the bacterial pathogen Xanthomonas campestris pv. malvacearum (Xcm) into the apoplasm of cotyledons from resistant cultivars of cotton (Gossypium hirsutum) induces a hypersensitive reaction (HR). The resistant cultivar Reba B50 contains the resistance gene combination B2$\mathrm{B} 3$ involved in gene-for-gene interactions with the $\mathrm{Xcm}$ avirulent race 18 (De Feyter et al. 1993; Innes 1983). By contrast, race 18 is virulent on the susceptible cultivar Acala 44 and spreads beyond infection sites, inducing characteristic leaf blight symptoms. Research on the nature of cotton resistance to bacterial blight has mainly focused on sesquiterpenoid phytoalexins, the major antimicrobial molecules produced by cotton plants (Essenberg and Pierce 1994). Flavonoids were also histochemically detected accumulating at sites where the HR developed (Dai et al. 1996). In a recent study, we showed that the activity of several peroxidases was locally stimulated in cells undergoing the HR in resistant cotyledons and systemically induced in whole plants (Martinez et al. 1996), but functional roles for these peroxidases were not elucidated.

In the present paper, we investigate the oxidative burst induced in cotyledons of the resistant cultivar Reba B50 by the $\mathrm{Xcm}$ avirulent race 18. Our experiments reveal that $\mathrm{O}_{2} \cdot{ }^{-}$is transiently produced in the extracellular apoplast during the first few hours of the incompatible interaction. Results suggest that the AOS production is generated by the activation of apoplastic peroxidases. We also present data demonstrating that both the resistant Reba B50 and susceptible Acala 44 cultivars contain an NADPH oxidase that remains inactive following infection by $\mathrm{Xcm}$.

\section{RESULTS}

In vivo characterization of the oxidative bursts in cotton cultivars Reba B50 and Acala 44.

Cytochrome c reducing activities were estimated with cotyledon disks of the two cultivars Reba B50 (Fig. 1) and Acala 44 (Fig. 2), resistant and susceptible to $\mathrm{Xcm}$ race 18 respectively, $3 \mathrm{~h}$ after either water infiltration or $\mathrm{Xcm}$ inoculation, or immediately after infiltration with $80 \mu \mathrm{M}$ digitonin.

Controls, infiltrated with water or with ethanol $(0.5 \%$ in water), showed slight extracellular reducing activities (Figs. $1 \mathrm{~A}$ and $2 \mathrm{~A}$ ) that were similar at $3 \mathrm{~h}$ to those estimated immediately after water treatment (data not shown). Intensities of the reducing activity (estimated by the initial slopes of the curves) differed between the two cultivars since activities in Reba B50 controls were twofold higher than in Acala 44 ones. These activities were 80 to $90 \%$ inhibited by the addition of superoxide dismutase (SOD) $(1,000 \mathrm{U} / \mathrm{ml})$ to the reaction medium (Figs. 1A and 2A), indicating that superoxide anion was the main component involved in the extracellular reduction of cytochrome c.

Three hours after infiltration of cotyledons from Acala 44 with $\mathrm{Xcm}$ race 18 (Fig. 1B) or from Reba B50 with $\mathrm{Xcm}$ race

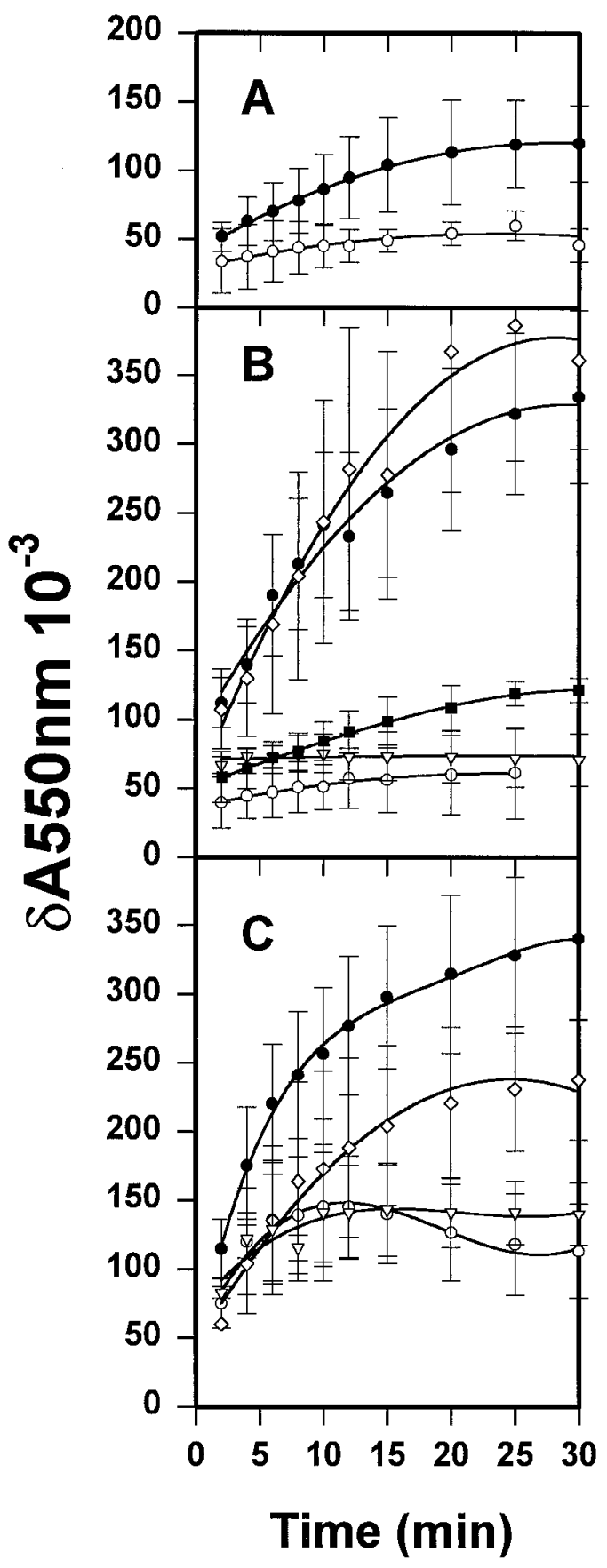

Fig. 1. Time course of extracellular cytochrome c-reducing activity of cotton cv. Reba B50 $3 \mathrm{~h}$ after infiltration with water (A, solid circles), Xanthomonas campestris pv. malvacearum $(\mathrm{Xcm})$ race $18(\mathbf{B}$, solid circles), or Xcm race 20 (B, solid squares), or immediately after infiltration with $80 \mu \mathrm{M}$ digitonin (C, solid circles). Absorbance at $550 \mathrm{~nm}$ of samples was read against a reference cuvette containing $20 \mu \mathrm{M}$ cytochrome $\mathrm{c}+100 \mu \mathrm{M}$ deferoxamine mesylate (DFO) in phosphate-buffered saline. Reducing activities were monitored in presence of $1,000 \mathrm{U} / \mathrm{ml}$ of superoxide dismutase (SOD) (open circles), $20 \mu \mathrm{M}$ diphenyleneiodonium chloride (DPI; open diamonds), or $50 \mu \mathrm{M} \mathrm{KCN} \mathrm{(open} \mathrm{triangles).} \mathrm{Values}$ are means \pm SD of three separate experiments with five replicates each. 
20 (Fig. 1B), the reducing activity remained similar to controls, whereas it was enhanced in race 18-infiltrated Reba B50 cotyledons to $300 \%$ of controls (Fig. 1B). This activity was $90 \%$ inhibited by the addition of SOD, totally blocked by $\mathrm{KCN}(50 \mu \mathrm{M})$, and insensitive to diphenyleneiodonium chloride (DPI) $(20 \mu \mathrm{M})$ (Fig. 1B). Higher concentrations of DPI (up to $100 \mu \mathrm{M}$ ) also failed to inhibit AOS generation.

Infiltration of cotyledons of both cultivars with $80 \mu \mathrm{M}$ digitonin immediately stimulated reducing activities (Figs. 1C and 2C) that were about threefold higher in Reba B50 than in Acala 44. Sixty percent of the activity in both cultivars was inhibited by SOD. The digitonin-induced cytochrome $\mathrm{c}$ reducing activities of both Reba B50 and Acala 44 were partially sensitive to DPI (33 and 19\% inhibition, respectively) and $\mathrm{KCN}$ (60 and 80\% inhibition, respectively).

Time course of changes in AOS production during cotton/Xcm interactions.

The superoxide anion production rates were estimated from the respective cytochrome $\mathrm{c}$ reducing activities. As shown in

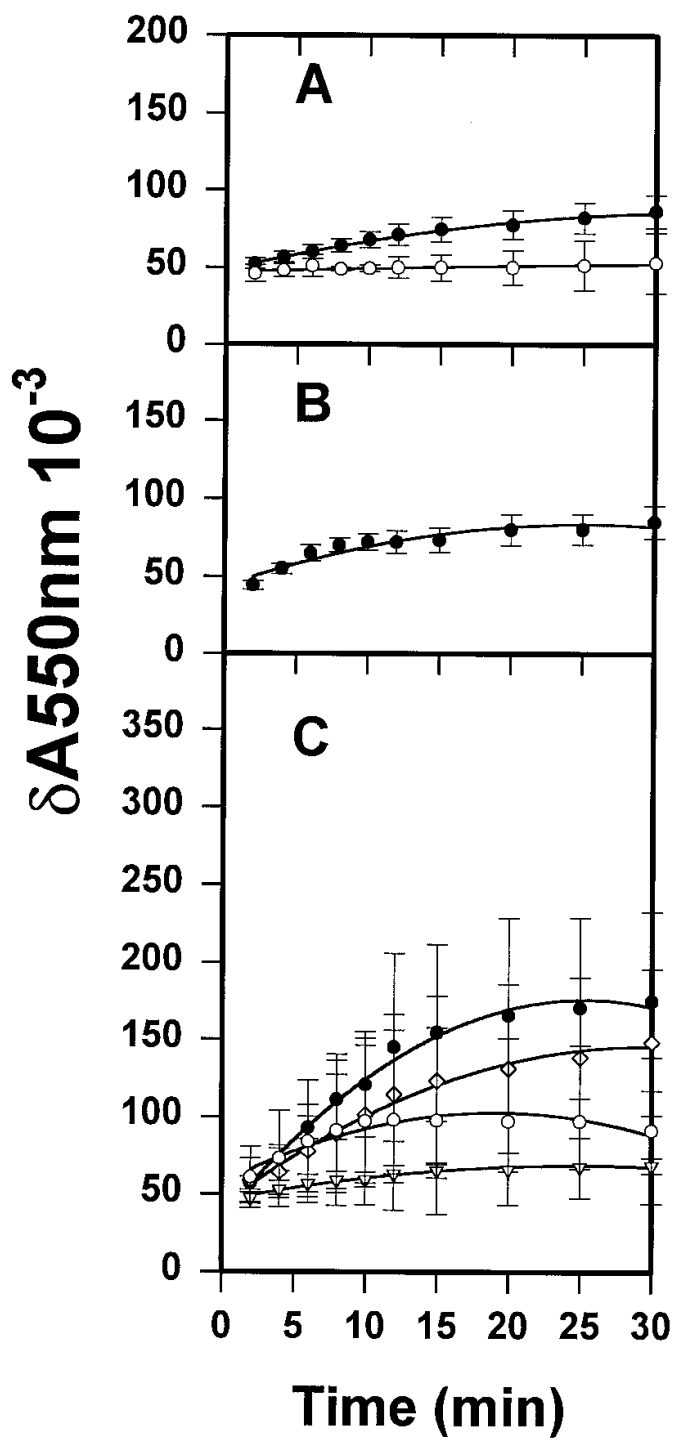

Fig. 2. Time course of extracellular cytochrome c-reducing activity of cotton cv. Acala 44. Inoculations, treatments and number of replicates were identical to those in Figure 1.
Figure 3, the incompatible interaction (Reba $\mathrm{B} 50 / \mathrm{Xcm}$ race 18) was characterized by a sharp peak of $\mathrm{O}_{2}{ }^{-}$production occurring between 2.5 and $3 \mathrm{~h}$ after infection. At that time, production of $\mathrm{O}_{2} \cdot{ }^{-}$was about $40 \mathrm{nmol} \mathrm{g}{ }^{-1} \mathrm{~min}^{-1}$. In the compatible interactions, Acala 44/Xcm race 18 and $\mathrm{Reba} \mathrm{B} 50 / \mathrm{Xcm}$ race20 (Fig. 3), a low basal production (not significantly different from controls) was observed over a 5-h period.

Hydrogen peroxide was histochemically detected with cerium chloride. $\mathrm{Ce}^{3+}$ was added to trap $\mathrm{H}_{2} \mathrm{O}_{2}$ as insoluble cerium perhydroxide that appears fluorescent after illumination of sections from the treated fragments with epipolarized ultraviolet light. Two hours after bacterial infiltration, no deposits of refractive particles were seen in the inoculated tissues, while 4 to $6 \mathrm{~h}$ after inoculation more fluorescence was seen in walls and in intercellular spaces of cotyledon cells challenged with bacteria (Fig. 4A) than observed in water-infiltrated controls (Fig. 4B). Fluorescence of walls was intense in the spongy mesophyll where the pathogen was inoculated but weak in palisade cells.

Inoculation of the susceptible cultivar with $\mathrm{Xcm}$ race 18 or infiltration with water did not yield any significant fluorescence. Similar results were obtained whether or not aminotriazole (catalase inhibitor) was added to the inoculum.

NADH oxidation activity in cotton cotyledons challenged with Xcm; time course changes and characterization.

NADH oxidation activity was assessed according to Halliwell (1978). The oxidation activity of crude cotyledon extracts was measured over $4 \mathrm{~h}$ following inoculation of Reba B50 and Acala 44 with $\mathrm{Xcm}$ race 18 (Fig. 5A). Constitutive activities, estimated in extracts from control samples, were $0.1 \pm 0.02$

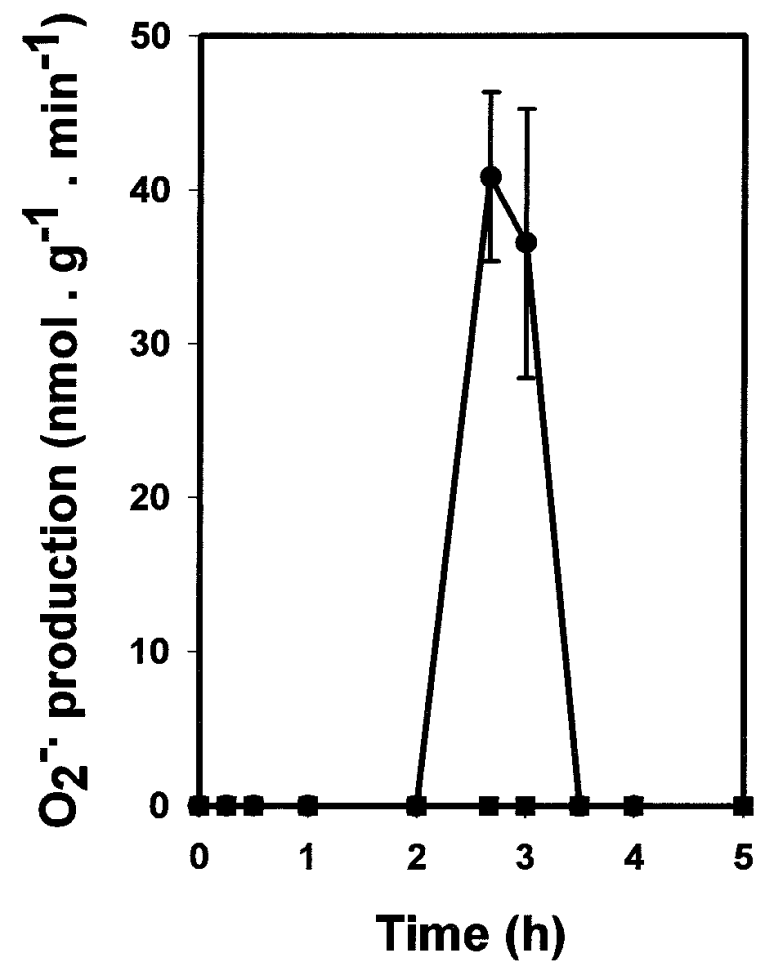

Fig. 3. Time course changes in $\mathrm{O}_{2} \cdot{ }^{-}$production; values of inoculated plants were substracted from the corresponding water infiltrated controls; (solid circles, Reba B50-Xcm race 18; solid squares, Reba B50race 20 , Acala 44-race 18 ). 
$\mathrm{nKat} \mathrm{mg}^{-1}$ protein for Reba B50 and $0.07 \pm 0.01 \mathrm{nKat}^{\mathrm{mg}} \mathrm{g}^{-1}$ protein for Acala 44. Whereas NADH oxidation activities remained unchanged during the compatible interaction, including that with $\mathrm{Xcm}$ race $20\left(0.09 \pm 0.02 \mathrm{nKat} \mathrm{mg}^{-1}\right.$ protein $)$, the incompatible interaction was characterized by a threefold increase in specific activity by $3 \mathrm{~h}$ after inoculation $(0.31 \pm 0.01$ $\mathrm{nKat} \mathrm{mg}^{-1}$ protein), which dropped to the basal level after $4 \mathrm{~h}$. As shown in Figure 5B, the activity of extracts obtained $3 \mathrm{~h}$ after inoculation of Reba B50 with Xcm race 18 was $75 \%$ inhibited when $\mathrm{KCN}(50 \mu \mathrm{M})$ or salicylhydroxamic acid (SHAM) $(5 \mathrm{mM})$ was added to the reaction mixture. In waterinfiltrated controls, the activity of extracts was only $42 \%$ inhibited, while a slight inhibition (15\%) in such activity was observed with Acala 44 extracts. Addition of $\mathrm{MnCl}_{2}(2 \mathrm{mM})$ or 2,4-dichlorophenol (2,4-DCP) $(17 \mu \mathrm{M})$, known to stimulate peroxidase activity (Halliwell 1978), strongly enhanced the specific activities of extracts obtained from both cotton cultivars. Activities in extracts from water-infiltrated or $\mathrm{Xcm}$ race 18-infected Reba B50 plants were statistically equivalent

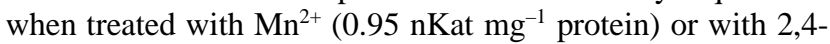
DCP (1.18 nKat $\mathrm{mg}^{-1}$ protein). The specific activities of Acala 44 extracts from both extracts reached the level of 0.45 and $0.49 \mathrm{nKat} \mathrm{mg}^{-1}$ protein when treated with $\mathrm{Mn}^{2+}$ or 2,4-DCP, respectively.

In a separate set of experiments, both NADH oxidation and guaiacol peroxidase activities were measured at $3 \mathrm{~h}$ in the crude extracts and in the apoplastic washing fluids (AWF) obtained from water and $\mathrm{Xcm}$ race 18-infiltrated resistant cultivar (Table 1). Both specific activities were higher in AWF
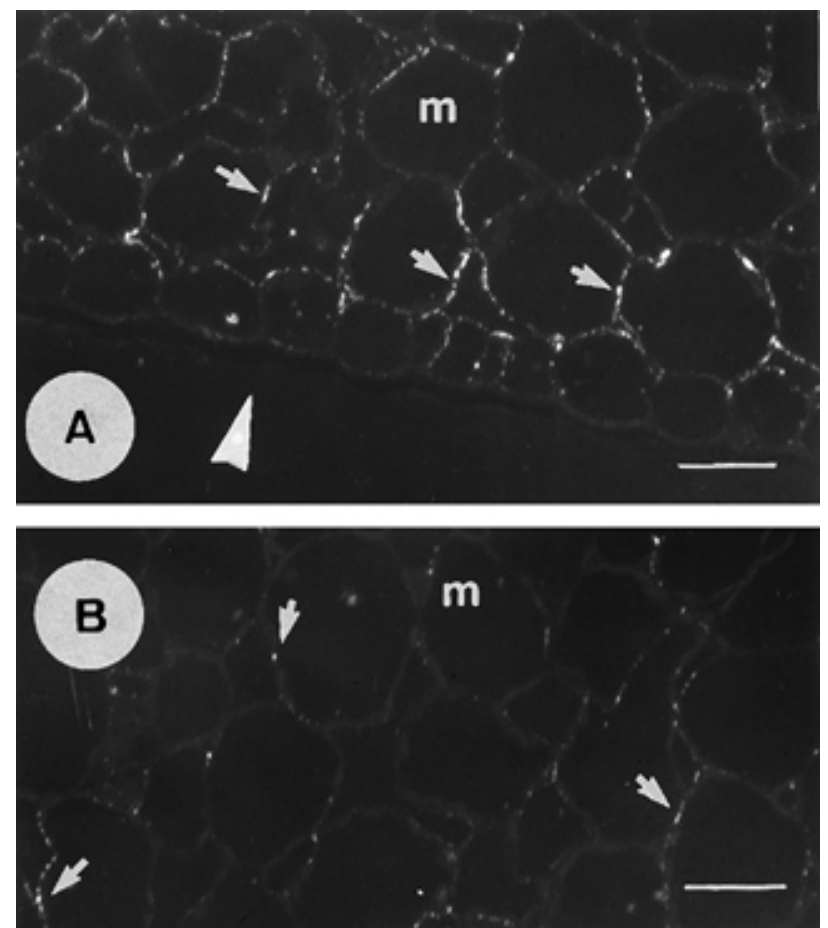

Fig. 4. Epipolarized fluorescence micrographs of the localization of $\mathrm{H}_{2} \mathrm{O}_{2}$. A, Four hours after infiltration of cotyledons of resistant plants of cotton cv. Reba B50 with the pathogen, intense fluorescence of walls (small arrows) is mainly observed in the spongy mesophyll (m) where the pathogen was inoculated (large arrow). Bar $=3 \mu \mathrm{m}$. B, After injection of water in resistant cotyledons, few cerium perhydroxide precipitates were seen in mesophyll (m) cell walls (arrows). Bar $=3 \mu \mathrm{m}$. than in crude extracts (about five- to sevenfold). Although no difference was spectrophotometrically detected in the guaiacol peroxidase activities between control and infected plants, the NADH oxidation activity was 2.4-fold higher in extracts from inoculated plants (Table 1) and differences in the activity of cationic peroxidase isozymes ( $\mathrm{pI} 9$ to 9.5 ) were observed on isoelectric focusing (IEF) gels (Fig. 6) only $3 \mathrm{~h}$ after inoculation of the resistant cultivar. Comparatively, no apparent modification in the strong staining intensity of the acidic peroxidase isoforms was observed from 0 to $12 \mathrm{~h}$ after infection. The optimum $\mathrm{pH}$ of this NADH oxidase activity was estimated at 5 .

\section{Cytochemical localization of peroxidase activity.}

Electron microscope observations of sections made in infected resistant cotyledons revealed weak electron-dense areas
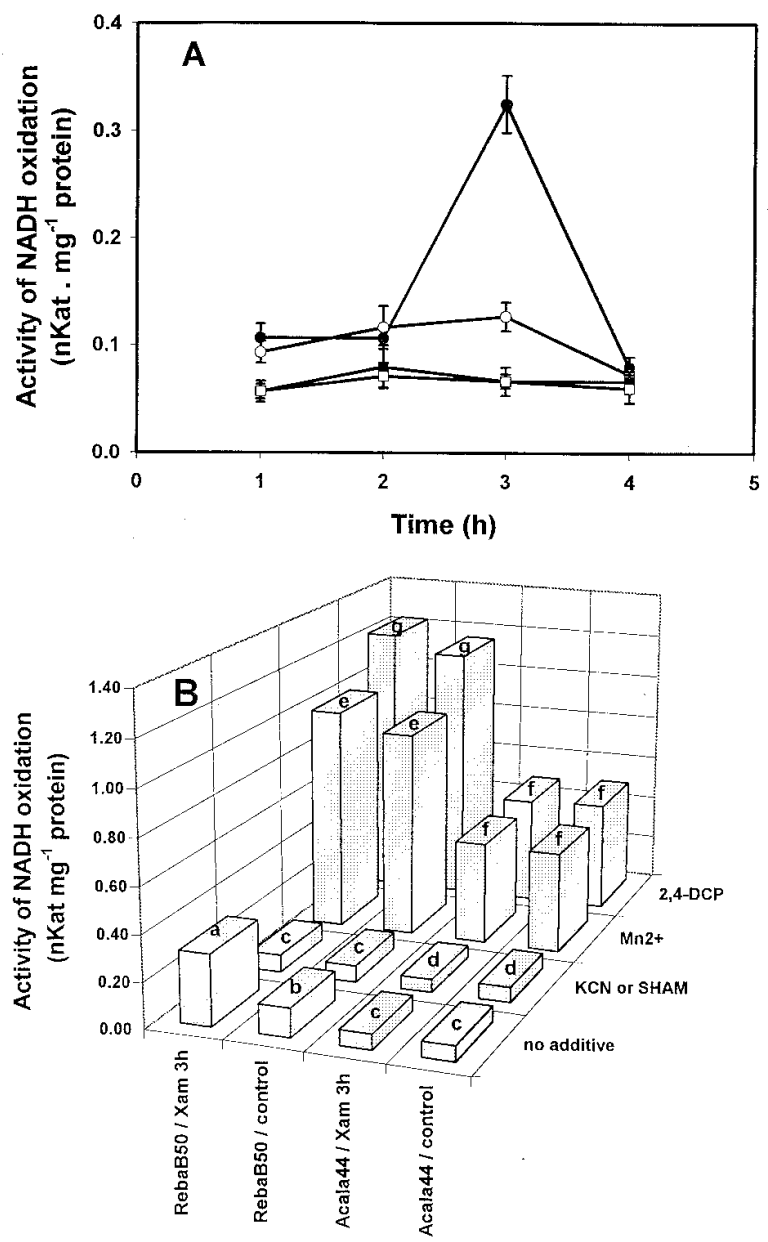

Fig. 5. A, Activity of NADH oxidation of crude enzymatic extracts of cotton cv. Reba B50 (solid circles, open circles) and Acala 44 (solid squares, open squares) inoculated with Xanthomonas campestris pv. malvacearum $(\mathrm{Xcm})$ race 18 . Open symbols correspond to NADH oxidation activity of water controls. Values are means \pm SD of two separate experiments with five replicates each. B, Effect of $50 \mu \mathrm{M} \mathrm{KCN}, 5 \mathrm{mM}$ salicylhydroxamic acid (SHAM), $2 \mathrm{mM} \mathrm{MnCl}_{2}$, and $17 \mu \mathrm{M}$ 2,4dichlorophenol (2,4-DCP) on specific NADH oxidation activity. Crude enzymatic extracts from cotton cvs. Reba B50 and Acala 44 were prepared $3 \mathrm{~h}$ post-inoculation with $\mathrm{Xcm}$ race 18 or after infiltration with water (see Materials and Methods). Compounds were added to the reaction buffer just before addition of enzymatic extracts. Values are means of two separate experiments with five replicates each; significant difference values are designated by different letters $(P=0.05)$. 
in the $\mathrm{Xcm}$-infiltrated zone 2 and $6 \mathrm{~h}$ after infection. By contrast, $3 \mathrm{~h}$ after infiltration, strong electron-dense areas were seen in the spongy mesophyll of the resistant cultivar. The middle lamella-bordering intercellular spaces in the spongy mesophyll, as well as wall areas, were strongly electron-dense (Fig. 7A). At this time, a weak reaction was observed in palisade mesophyll cells (Fig. 7B). Electron-dense areas were sometimes, but not always, seen at sites of attachment of bacteria into the surrounding middle lamella (Fig. 7C). After injection with deionized water, cotyledons of resistant plants showed a weak electron density in cell walls (Fig. 7D). In infected cotyledons of susceptible plants, a slight peroxidase activity was found in the tonoplast (Fig. 7E), but not in the middle lamella and the cell walls. Incubation of sections in medium without $\mathrm{H}_{2} \mathrm{O}_{2}$ did not induce any electron density (Fig. 7F).

\section{DISCUSSION}

An important feature of plant resistance responses toward invading pathogens is thought to be the rapid production of AOS, a phenomenon known as the "oxidative burst" (Baker and Orlandi 1995). There is evidence that AOS generators may closely resemble those involved in the respiratory burst in mammalian phagocytes (Medhy 1994), with similar features such as (i) involvement of a plasma membrane-bound NADPH oxidase activity (Desikan et al. 1996; Murphy and Auh 1996; Ogawa et al. 1997; Simon-Plas et al. 1997), (ii) existence of the rbohA gene homologue of the mammalian gp91phox (Groom et al. 1996; Keller et al. 1998), and (iii) immunologically related peptides (Levine et al. 1994; Dwyer et al. 1995; Kiefer et al. 1997). Several other enzymes have been proposed as the source of AOS production during plant pathogenesis, including lipoxygenases, oxalate-oxidase, xanthine-oxidase, amine-oxidases, and peroxidases (Vera-Estrella et al. 1992; Adam et al. 1995; Baker and Orlandi 1995; Allan and Fluhr 1997; Lamb and Dixon 1997). Bolwell et al. (1995) demonstrated that generation of $\mathrm{H}_{2} \mathrm{O}_{2}$ by peroxidases was not consistent with production of intermediate superoxide anions characteristic of the plasmalemma NADPH oxidase. Although some experimental data indicate that several sources of AOS are potentially functional in a given plant cell (Allan and Fluhr 1997), it is reasonable to hypothesize that this could be a gen-

Table 1. Comparison of NADH oxidation levels and total guaiacol activities between crude extracts and apoplastic fluids from the resistant cultivar

\begin{tabular}{|c|c|c|c|c|}
\hline \multirow[b]{2}{*}{ Treatments } & \multicolumn{2}{|c|}{ Crude extracts } & \multicolumn{2}{|c|}{ Apoplastic fluids ${ }^{a}$} \\
\hline & $\begin{array}{c}\text { NADH } \\
\text { oxidation }^{b}\end{array}$ & $\begin{array}{l}\text { Guaiacol } \\
\text { activity }^{\text {b,c }}\end{array}$ & $\begin{array}{c}\text { NADH } \\
\text { oxidation }\end{array}$ & $\begin{array}{l}\text { Guaiacol } \\
\text { activity }^{b, c}\end{array}$ \\
\hline Control $^{\mathrm{d}}$ & $0.21 \pm 0.05$ & $36.3 \pm 7.9$ & $1.14 \pm 0.58$ & $257 \pm 65.4$ \\
\hline $\begin{array}{l}\text { Infected } \\
\text { cotyledons }\end{array}$ & $0.5 \pm 0.16$ & $39.3 \pm 7.15$ & $2.67 \pm 0.19$ & $255 \pm 55.6$ \\
\hline
\end{tabular}

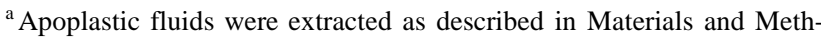
ods.

${ }^{\mathrm{b}}$ Activity expressed as nKat per $\mathrm{mg}^{-1}$ of protein $\pm \mathrm{SD}$ as mean of 10 replicates (five plants).

${ }^{c}$ Guaiacol was used as the peroxidase substrate.

${ }^{\mathrm{d}}$ Cotyledons were infiltrated with water.

e Cotyledons were infiltrated with Xanthomonas campestris pv. malvacearum $(\mathrm{Xcm})$ race 18 . eral feature. However, there is insufficient evidence to understand how "crosstalk" may operate between the plant and the pathogen that leads to the activation of a particular AOS production pathway. It cannot be excluded that different AOS sources could be sequentially or simultaneously elicited during a plant-pathogen interaction, as emphasized by Wojtaszeck (1997).

In the present work, several lines of evidence demonstrate that superoxide anions and hydrogen peroxide were produced during the incompatible interaction between cotton cotyledons and $\mathrm{Xcm}$, but not during the susceptible interactions. In response to inoculation of Reba $\mathrm{B} 50$ cotyledons with $\mathrm{Xcm}$ race 18 , a threefold increase in extracellular cytochrome $\mathrm{c}$ reducing activity was observed relative to water controls at $3 \mathrm{~h}$ postinoculation, whereas activity in Acala 44 cotyledons remained unchanged. Since the reducing activity in Reba B50 cotyledons was inhibited $90 \%$ by SOD, totally blocked by $\mathrm{KCN}$, and insensitive to DPI, we postulated that the $\mathrm{O}_{2} \cdot{ }^{-}$production was mediated by peroxidase activity.

Treatment with digitonin, a steroid glycoalkaloid known to elicit the production of $\mathrm{O}_{2}{ }^{-}$in various plant species (Doke and Chain 1985), resulted in an immediate increase in the extracellular reducing activity in both cultivars that was inhibited to about $60 \%$ by addition of SOD. This probably reflected that digitonin not only elicited the production of $\mathrm{O}_{2}{ }^{-}$but also triggered an oxygen-independent process able to reduce the cytochrome c. In both cultivars, a part of the digitonin-induced activity was inhibited by DPI, suggesting that digitonin was able, as earlier described by Doke and Miura (1995), to stimulate production of $\mathrm{O}_{2}{ }^{-}$through elicitation of an NADPH oxidase activity. In addition, $\mathrm{KCN}$ was shown to inhibit strongly the digitonin-stimulated reducing activity in both cultivars, suggesting that part of KCN inhibition could be explained by its action on a putative digitonin-elicited peroxidase and also by its effect on the oxygen-independent process. From our data, it appears that in cotton cotyledons, digitonin elicited a complex process leading to the extracellular reduction of cytochrome c. At least one component of this process was not dependent on oxygen (insensitive to the action of $\mathrm{SOD}$ ), and was inhibited by $\mathrm{KCN}$, while the oxygendependent component was partially inhibited by DPI and by

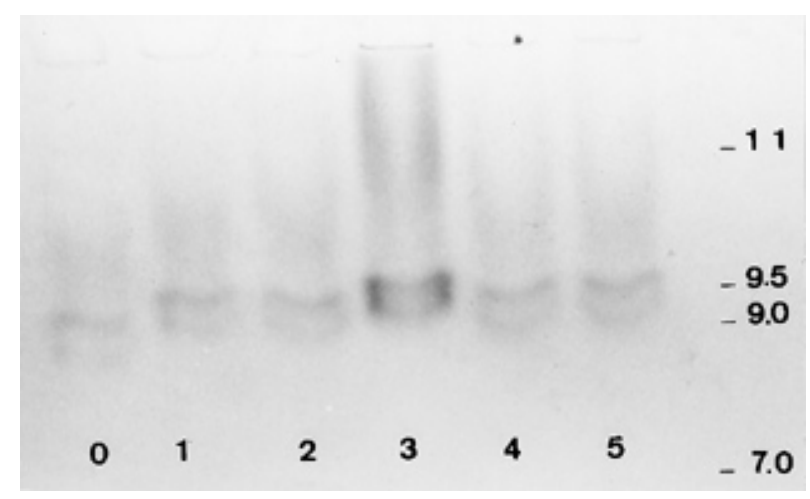

Fig. 6. Analytical isoelectric focusing (IEF) according to time ( 0 to $5 \mathrm{~h}$; lanes 0 to 5) of samples from resistant cotton cv. Reba B50 infected with Xanthomonas campestris pv. malvacearum (Xcm) race 18. Cationic peroxidase isozymes (pI 9 to 9.5) were separated on an IEF gel ( $\mathrm{pH} 3$ to 11) followed by guaiacol staining. $\mathrm{Gel} \mathrm{pH}$ is shown in right margin. Increase in activity is observed $3 \mathrm{~h}$ following inoculation (lane 3 ). 


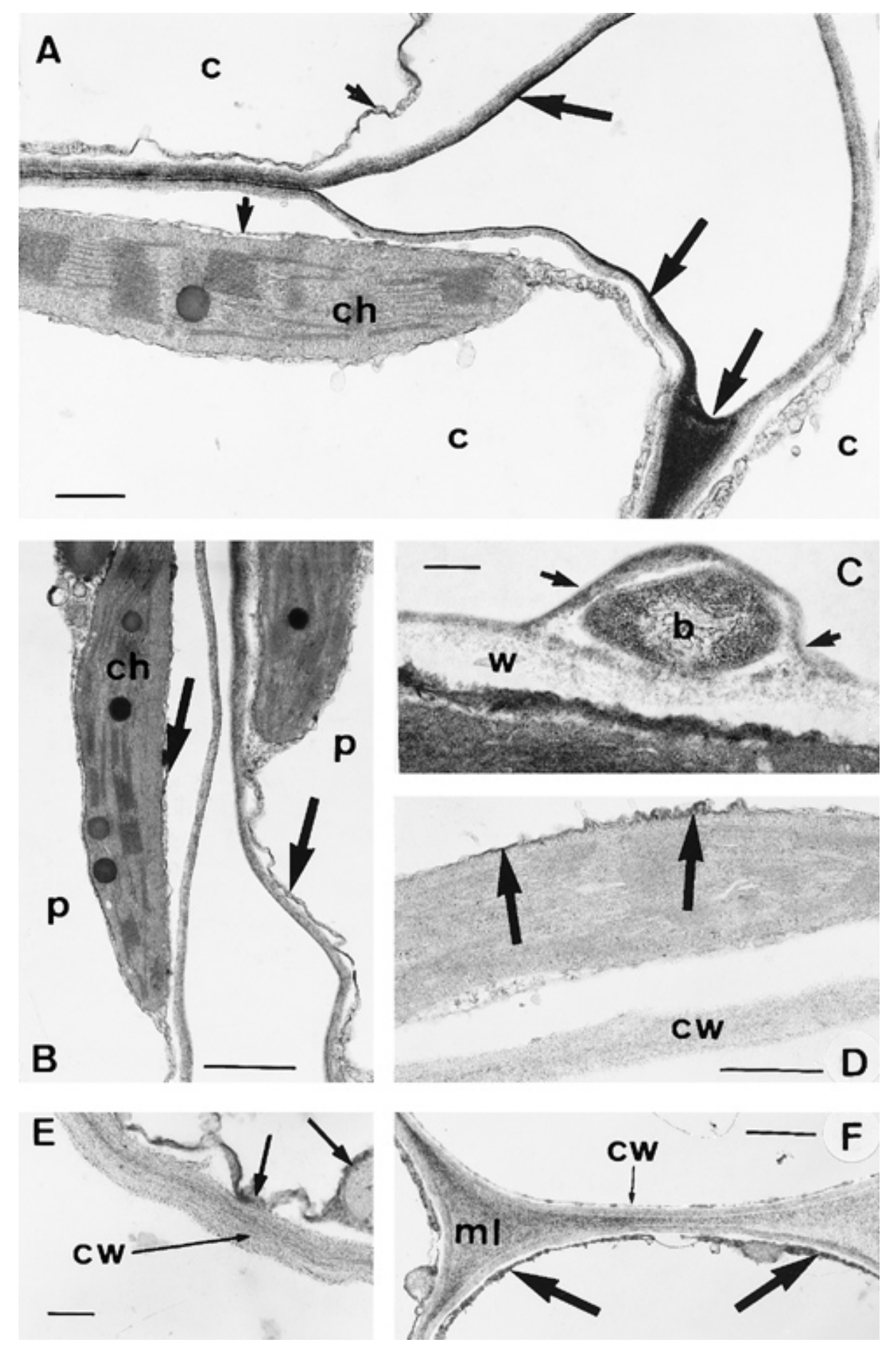

Fig. 7. A and B, Transmission electron micrographs of the localization of peroxidase activity, $3 \mathrm{~h}$ after infiltration of cotyledons of resistant cotton cv. Reba B50 plants with Xanthomonas campestris pv. malvacearum $(\mathrm{Xcm})$ race 18. Strong electron-dense areas are seen in the middle lamella (arrows) of these spongy mesophyll cells (c), indicating presence of peroxidase activity (A). This activity is also located in plasma membrane (arrowheads). In the palisade parenchyma cells (p) (B), a weak peroxidase activity is seen in the plasma membrane (arrows) and the cell wall $(\mathrm{ch}=\mathrm{chloroplast})$. Bar $=(\mathbf{A}) 0.5$ and (B) $1 \mu \mathrm{m}$. C, Electron-dense middle lamella showing peroxidase activity (arrows) surrounding site of attachment of bacteria close to cell wall (w). Bar $=0.3 \mu \mathrm{m}$. D, Control; Transmission electron micrograph of localization of peroxidase activity, $3 \mathrm{~h}$ after infiltration of cotyledons of resistant cotton cv. Reba B50 with dionized water. A peroxidase activity is seen in the tonoplast of a spongy mesophyll cell as indicated by the weak electron density (arrows). No strong electron density is seen in primary cell wall $(\mathrm{cw})$ and middle lamella. Bar $=0.5 \mu \mathrm{m}$. E, Transmission electron micrograph of localization of peroxidase activity, $3 \mathrm{~h}$ after infiltration of cotyledons of susceptible cotton cv. Acala 44 with Xcm. Slight peroxidase activity is detected in vacuole membrane (arrows). No significant increase in electron densisty is visible in primary cell wall (cw) of this spongy mesophyll cell. ch $=$ chloroplast. $\mathrm{Bar}=0.5 \mu \mathrm{m}$. F, Control in which $\mathrm{H}_{2} \mathrm{O}_{2}$ was omitted in the reaction volume for assessing activity. Transmission electron micrograph of localization of peroxidase activity, $3 \mathrm{~h}$ after infiltration of cotyledons of resistant cv. Reba B 50 with Xcm. A weak electron density only is observed in cytoplasm (arrows) and middle lamella (ml), but not in cell wall (cw). Bar $=1 \mu \mathrm{m}$. 
$\mathrm{KCN}$. This suggests that the latter process depended on the digitonin-mediated activation of both an NADPH oxidase and a peroxidase, indicating that both cotton cultivars display the two enzymatic systems, each of them being able to produce extracellular $\mathrm{O}_{2}{ }^{-}{ }^{-}$. The ability of Acala 44 cotyledons to produce $\mathrm{O}_{2} \cdot{ }^{-}$in response to digitonin was, however, significantly less than that of Reba B50. These observations are in accordance with previous work reporting that plant cultivars without major gene(s) for resistance to their pathogens also carry the system for the oxidative burst (Doke et al. 1996).

Following inoculation with $\mathrm{Xcm}$ race 18 , cotyledons from Reba B50 plants were characterized by a sharp burst of $\mathrm{O}_{2}{ }^{-}$ between 2 and $3 \mathrm{~h}$ through the activation of a putative peroxidase, while the susceptible cultivar Acala 44 was unable to elicit any AOS production. Similarly, the other compatible interaction, Reba $\mathrm{B} 50 / \mathrm{Xcm}$ race 20 , did not result in the development of an oxidative burst. Whereas crude enzymatic extracts prepared from cotyledons of Acala 44 inoculated with $\mathrm{Xcm}$ race 18 or of Reba $\mathrm{B} 50$ inoculated with $\mathrm{Xcm}$ race 20 did not show any increase in the specific activity of NADH oxidase, those from cotyledons collected from $\mathrm{Xcm}$ race 18 infected Reba B50 plants showed a threefold higher activity, 3 $\mathrm{h}$ after infection. The time course of increase in NADH oxidase activity correlated that of AOS production. Activity was blocked by the peroxidase inhibitors KCN or SHAM but was strongly stimulated by $\mathrm{Mn}^{2+}$ ions or 2,4-DCP, which were both described as powerful stimulating agents of peroxidase (Halliwell 1978). Two striking points are worth emphasis: (i) in the presence of peroxidase stimulators the oxidation of NADH was statistically similar between Reba B50 samples from inoculated and control plants; and (ii) in the same conditions of treatment, these activities in Acala 44 were high and even higher than that after $3 \mathrm{~h}$ post-inoculation in Reba B50 samples. Since in the presence of these activating agents, (i) the specific NADH oxidase activity increased immediately after their addition in the reaction medium, and (ii) samples prepared from inoculated and control plants showed no difference in this activity, we proposed that elicitation of the putative AOS-producing peroxidase was regulated at the posttranscriptional level.

It is also suggested from our data that the NADH oxidase activity is localized extracellularly, since we showed that its specific activity was higher in AWF than in crude extracts. AWF also possessed a very high and constitutive guaiacol peroxidase activity. This was confirmed on IEF gels that showed strong and constant guaiacol staining in the acidic zone of the gel (not shown) and a low staining supported by cationic peroxidase isozymes (pI 9 to 9.5), the activity of which clearly increased at $3 \mathrm{~h}$ only in extracts from race 18inoculated resistant cotyledons. Our cytochemical investigations with $\mathrm{DAB}$ as a peroxidase substrate also revealed that, 3 $\mathrm{h}$ after inoculation, the activity of some extracellular peroxidases was strongly elicited in plant cell walls and middle lamellae during the incompatible interaction. These observations further strengthen our biochemical data, being in accordance with the assumption of Bolwell et al. (1995) that AOS-generating peroxidases are wall bound. However, taking into account the high constitutive and extracellular guaiacolperoxidase activity present, we must assume that DAB would be a better substrate for cationic peroxidases, and subsequently we must assess their activity at the ultrastructural level. Our preliminary investigations revealed an optimum $\mathrm{pH}$ of 5 for the NADH oxidase activity. Interestingly, Nair and Showalter (1996) have recently isolated in carrot roots a cell wall cationic peroxidase ( $\mathrm{pI}>9.3$ ), the activity of which was induced by wounding. They showed that this wound-inducible peroxidase has an optimum $\mathrm{pH}$ at 4.9 and suggested that it could be regulated at post-transcriptional level. These observations are, however, different from the report by Bolwell et al. (1995) of two bean $\mathrm{H}_{2} \mathrm{O}_{2}$-generating peroxidases having a neutral and a slightly alkaline optimum $\mathrm{pH}$. Moreover, as mentioned by these authors, the transient alkalinization that takes place in the apoplasm of elicited bean cells could favor the activity of a wall-bound cationic peroxidase, leading to $\mathrm{H}_{2} \mathrm{O}_{2}$ synthesis. Based on the assumption that $\mathrm{O}_{2} \cdot{ }^{-}$production in cotton/Xcm incompatible interaction is generated by the activity of an extracellular cationic peroxidase having an acidic optimum $\mathrm{pH}$, investigation of extracellular $\mathrm{pH}$ modifications in infected cotton mesophyll cells should be revealing. Purification of the cotton wall-bound cationic peroxidase isozymes will confirm in vitro their potent role in planta.

The present data strongly suggest that cotton cotyledons can generate extracellular $\mathrm{O}_{2}{ }^{-}$through two distinct enzymes, a $\mathrm{KCN}$-sensitive peroxidase with $\mathrm{NADH}$ oxidase activity and DPI-sensitive NADPH oxidase. In our experiments, the production of $\mathrm{O}_{2} \cdot{ }^{-}$during the incompatible interaction was exclusively mediated through the activation of apoplastic peroxidase(s), the DPI-sensitive NADPH oxidase remaining silent. To our knowledge, this is the first time that peroxidase activity is reported to contribute to $\mathrm{O}_{2}{ }^{-}$production in planta, despite the presence of an NADPH oxidase. Nevertheless, the presence of both types of enzyme has already been demonstrated in tobacco tissues (Allan and Fluhr 1997); additionally, it was recently shown with isolated plant cell walls from pea and cowpea that wall-bound peroxidase activity leads to the production of $\mathrm{O}_{2}{ }^{-}$(Kiba et al. 1997). Accordingly, our data indicate that peroxidase $\mathrm{O}_{2}{ }^{-}{ }^{-}$-generating activity can now be considered an alternative mechanism to the plasma membrane NADPH oxidase, as already suggested by Bestwick et al. (1997), Lamb and Dixon (1997), and Wojtaszeck (1997).

Bolwell et al. (1995) have stated that peroxidase-dependent production of AOS in French bean cells infected with Colletotrichum lindemuthianum was neither inhibited by SOD nor measurable by the reduction of cytochrome $\mathrm{c}$, concluding that $\mathrm{H}_{2} \mathrm{O}_{2}$ was the AOS produced in this system during the oxidative burst. We also demonstrated by epipolarized microscopical observations that $\mathrm{H}_{2} \mathrm{O}_{2}$ accumulated in the apoplast of the resistant cotyledon cells infected by $\mathrm{Xcm}$ race $18 . \mathrm{H}_{2} \mathrm{O}_{2}$ was visible at this site from $4 \mathrm{~h}$ and was still present at $6 \mathrm{~h}$. Persistence of this diffusible AOS at the extracellular level during at least $2 \mathrm{~h}$ could be interpreted as resulting from synthesis still active at that time. Although $\mathrm{H}_{2} \mathrm{O}_{2}$ synthesis could partly result from dismutation of $\mathrm{O}_{2} \cdot{ }^{-}$, the production of which occurred between 2.5 and $3 \mathrm{~h}$ after inoculation, it is reasonable to propose an additional source for $\mathrm{H}_{2} \mathrm{O}_{2}$, in as much as $\mathrm{O}_{2}{ }^{-}$ was no longer produced after $4 \mathrm{~h}$. Correlatively, NADH oxidase activity returned to its basal level at that time. In a nonhost lettuce/Pseudomonas syringae system, Bestwick et al. (1997) hypothesized that $\mathrm{H}_{2} \mathrm{O}_{2}$ that was not rapidly metabolized plays an important role in the plasma membrane breakdown at sites of bacterial attachment. Although we have found that bacteria could be attached to cell walls or the middle la- 
mella that displayed peroxidase activity, we were not able to demonstrate in the cotton/Xcm system a close relationship between sites of peroxidase activity and AOS production, and a possible AOS toxicity toward the pathogen as reported by Bestwick et al. (1997). $\mathrm{H}_{2} \mathrm{O}_{2}$ generated during the oxidative burst has been suggested to be required for longer term defense responses such as lignification (Apostol et al. 1989; Levine et al. 1994). The link between AOS metabolism, cell wall peroxidase activity, and lignification has been reported in various incompatible systems (Milosevic and Sluzarenko 1996; Ogawa et al. 1997; J. M. Chittor, J. E. Leach, and F. F. White, unpublished), including Xanthomonas sp.-infected rice (Young et al. 1995; Leach et al. 1996). In our model, although peroxidase activity and $\mathrm{H}_{2} \mathrm{O}_{2}$ were detected in cell walls within the necrotic lesions, no lignin or suberin was found at these sites by histochemical methods (Dai et al. 1996).

AOS from the oxidative burst have been postulated to play a central role in triggering HR cell death and defense genes in challenged cells (Greenberg et al. 1994; Hammond-Kosak and Jones 1996; Levine et al. 1994; Tenhaken et al. 1995; Dangl et al. 1996; Mittler and Lam 1996). Extracellular generation of $\mathrm{O}_{2} \cdot{ }^{-}$by cell wall peroxidases in cotton cotyledons during the incompatible interaction with $\mathrm{Xcm}$, despite the presence of a DPI-sensitive NADPH oxidase, opens interesting avenues on the role that AOS may play in elicitation of HR cell death and plant resistance. Jabs et al. (1996) demonstrated that $\mathrm{O}_{2}{ }^{-}$- was necessary and sufficient to initiate lesions and cell death in a mutant $A$. thaliana plant. Superoxide anions were also shown to be able to trigger phytoalexin synthesis in parsley cells (Jabs et al. 1997). In this respect, the place of AOS, including $\mathrm{H}_{2} \mathrm{O}_{2}$, in cotton resistance is currently under investigation with emphasis on local and systemic responses. In addition, the involvement of extracellular peroxidase in the production of AOS during the oxidative burst raises the question of the key role played by the cell wall and the apoplasm in the plant responses to pathogens. Accordingly, identification of the extracellular peroxidase substrate(s) at that site is of crucial interest. Finally, it has been shown that HR phenotype varies following gene-for-gene interactions (Mansfield et al. 1997). Since cotton cells are able to produce $\mathrm{O}_{2}{ }^{-}$by two different enzymes, it would be of critical importance to know whether or not elicitation of the oxidative burst via a particular route is pathogen-dependent and a direct result of specific elicitor/receptor binding.

\section{MATERIALS AND METHODS}

Biological materials, inoculation, and treatment of plants.

Two cotton cultivars ( $G$. hirsutum) were used in this study. The susceptible Acala 44 cultivar possesses no known major genes for resistance to Xcm (Hunter et al. 1968; De Feyter et al. 1993). The Reba B50 cultivar (Allen $\times$ Stoneville 2B), similar to the 101-102B line, contains the B2B3 blight resistance key genes, which confer immunity to all $\mathrm{Xcm}$ races, including race 18, except race 20 (Hillocks 1992; Innes 1983). Both cultivars were inoculated by infiltration of the bacterial suspension $\left(10^{7}\right.$ to $\left.10^{8} \mathrm{CFU} / \mathrm{ml}\right)$ as described by Dai et al. (1996). So far, three interactions have been tested: one incompatible, Reba $\mathrm{B} 50 / \mathrm{Xcm}$ race 18 , and two compatible, Reba $\mathrm{B} 50 / \mathrm{Xcm}$ race 20 and Acala- $44 / \mathrm{Xcm}$ race 18 . Controls consisted of plants from each cultivar that were infiltrated with sterile water.
In other experiments, cotyledonary leaves were also infiltrated with digitonin solutions $(80 \mu \mathrm{M}$ in water containing $0.5 \%$ ethanol). Inoculated plants and those treated with digitonin were assayed for their extracellular cytochrome c reducing activities.

\section{Assay of extracellular cytochrome c reducing activity of cotyledon disks.}

The $\mathrm{O}_{2}{ }^{-}$generating activity of cotyledon disks was assayed by measuring spectrophotometrically the reduction of exogenously supplied cytochrome c (Doke 1983). Inoculated plants were assayed at different times after bacterial or water (control) infiltration, whereas digitonin-treated ones were tested immediately. Ten cotyledon disks (each $1 \mathrm{~cm}$ in diameter) were immersed by gently shaking in $20 \mathrm{ml}$ of a reaction mixture consisting of $20 \mu \mathrm{M}$ bovine heart cytochrome $\mathrm{c}$ and $100 \mu \mathrm{M}$ deferoxamine mesylate (DFO) in $0.05 \mathrm{M} \mathrm{pH} 7.8$ phosphate-buffered saline (PBS). Traces of metal impurities were previously removed by treatment of PBS with chelex100 (100 to 200 mesh) according to Sanders et al. (1994). Absorbance of the sample was measured at regular intervals at $550 \mathrm{~nm}$ with a double-beam spectrophotometer (Uvikon 922; Kontron, Marseille, France), against a reference cuvette containing the reaction buffer $(\mathrm{PBS}+20 \mu \mathrm{M}$ cytochrome $\mathrm{c}+100$ $\mu \mathrm{M}$ DFO). The $\mathrm{O}_{2} \cdot{ }^{-}$-mediated reduction of cytochrome $\mathrm{c}$ was estimated by adding $1,000 \mathrm{U} \mathrm{m}^{-1}$ of SOD in the reaction buffer just before addition of cotyledon disks. The $\mathrm{O}_{2}{ }^{-}$production rates were determined by measuring the initial slopes of the curves (increase in absorbance at $550 \mathrm{~nm}$ during the first 8 to $10 \mathrm{~min}$ ) taking into account the inhibition scores with SOD and molar absorbtivities for ferricytochrome c (0.89 10 $\left.\mathrm{M}^{-1} \mathrm{~cm}^{-1}\right)$ and ferrocytochrome c $\left(2.9910^{4} \mathrm{M}^{-1} \mathrm{~cm}^{-1}\right)$ at 550 $\mathrm{nm}$. KCN $(50 \mu \mathrm{M})$ or SHAM $(5 \mathrm{mM})$ was added to the reaction buffer before immersion of cotyledon disks to tentatively evaluate the role of peroxidases as extracellular generators of cytochrome c reducing compounds. Similarly, DPI $(20 \mu \mathrm{M})$ was used as inhibitor of an NADPH oxidase.

\section{Preparation of crude extracts and AWF from cotton cotyledons.}

Cotyledons from infected plants and controls were harvested $0,1,2,3,4,12$, and $24 \mathrm{~h}$ after inoculation. They were crushed and homogenized in $0.05 \mathrm{M} \mathrm{pH} 6$ sodium acetate buffer $(2 \mathrm{ml}$ per $\mathrm{g}$ of fresh weight) containing $25 \mathrm{mM} \beta$ mercapto-ethanol, and 5\% polyvinylpolypyrolidone. After centrifugation $(15 \mathrm{~min}$ at $12,000 \times \mathrm{g})$, the supernatant was filtered on polyether-sulfone membrane $(0.45 \mu \mathrm{m}$, Nalgène; Hereford, England). AWFs were prepared according to Polle et al. (1994), where sodium buffer was used instead of MES (morpholinoethanesulfonic acid) buffer.

\section{Assay of NADH oxidase.}

Enzymatic activities were determined on crude extracts or on AWF, $3 \mathrm{~h}$ after inoculation or water infiltration. NADH oxidation activity was measuring by monitoring the decrease in absorbance at $340 \mathrm{~nm}$. The reaction mixture $(1 \mathrm{ml}$ final volume) consisted of $50 \mathrm{mM} \mathrm{pH} 5$ sodium acetate buffer and $0.15 \mathrm{mM}$ NADH (Halliwell 1978). The reaction was initiated by adding the enzymatic extract (50 to $200 \mu \mathrm{l}$ ) and was followed from 0 to $15 \mathrm{~min}$. Effect of SHAM, KCN, or the peroxidase activators 2,4-DCP $(17 \mu \mathrm{M})$ or $\mathrm{MnCl}_{2}(2 \mathrm{mM})$ was tested 
after addition in the reaction mixture; NADH oxidation activity was then immediately assessed. Activities were calculated with a molar extinction coefficient of $6,300 \mathrm{M}^{-1} \mathrm{~cm}^{-1}$ for NADH. Protein concentration was determined according to Bradford (1976) with bovine serum albumin (BSA) as a standard.

IEF.

Crude extracts were separated under nondenaturing conditions, in $70 \times 80 \mathrm{~mm}$ glass sheaths (Bio-Rad Laboratories, Hercules, CA), by IEF according to Robertson et al. (1987). The $\mathrm{pH}$ gradient of the gel ranged from 3 to 11. Ampholytes $3 / 10$ and $9 / 11(1 / 4, \mathrm{vol} / \mathrm{vol})$ were used at a final concentration of $12 \%$ ( $\mathrm{vol} / \mathrm{vol})$. The anode solution consisted of $20 \mathrm{mM}$ acetic acid and the cathode solution of $25 \mathrm{mM} \mathrm{NaOH}$. After migration, peroxidases were localized by incubating gels in a staining buffer consisting of $0.05 \mathrm{M} \mathrm{pH} 6$ sodium phosphate buffer containing guaiacol $0.2 \%$ (wt/vol), $0.01 \%$ 3-amino-9ethylcarbazole (wt/vol), and $0.03 \%$ (vol/vol) $\mathrm{H}_{2} \mathrm{O}_{2}$. The gel lane corresponding to the isoelectric point marker was cut off and stained with Coomassie blue R-250. In the absence of $\mathrm{H}_{2} \mathrm{O}_{2}$ no staining was observed. The experiment, carried out 1 , $2,3,4,5$, and $6 \mathrm{~h}$ after $\mathrm{Xcm}$ or water infiltration, was performed five times, with three infected plants and three plants per controls at each time.

\section{Peroxidase assay and protein determination.}

Assays of peroxidase activities of the extracts were carried out with guaiacol as the hydrogen donor. Activities were estimated from increase in absorbance at $470 \mathrm{~nm} / \mathrm{min}$. Total activity was expressed in $\mathrm{nKa}$ per $\mathrm{mg}$ of proteins. Protein determination was performed by the method of Bradford (1976) BSA as a standard. Estimation of proteins and peroxidase activities was performed on cotyledon proteic extracts sampled $0,1,2,4,6,8,10,12,24,48$, and $72 \mathrm{~h}$ after inoculation.

\section{Ultrastructural localization of peroxidase activity.}

Fragments of cotyledons were sampled 2, 3, and $6 \mathrm{~h}$ postinoculation and fixed in $2.5 \%$ ( $\mathrm{vol} / \mathrm{vol})$ glutaraldehyde in 0.05 $\mathrm{M}$ phosphate buffer ( $\mathrm{pH} \mathrm{6.8)}$ ) for $1 \mathrm{~h}$, washed in buffer for 30 min, and incubated at $37^{\circ} \mathrm{C}$ for $3 \mathrm{~h}$ in a solution of $3,3^{\prime}$ diaminobenzidine tetrahydrochloride (DAB) consisting of 5 $\mathrm{mg}$ of $\mathrm{DAB}$ in $10 \mathrm{ml}$ of $0.05 \mathrm{M} \mathrm{pH} \mathrm{7.6} \mathrm{Tris-HCl} \mathrm{buffer} \mathrm{and}$ $0.1 \mathrm{ml}$ of $1 \%$ (vol/vol) $\mathrm{H}_{2} \mathrm{O}_{2}$. Following incubation, all preparations were postfixed in $2 \%(\mathrm{wt} / \mathrm{vol}) \mathrm{OsO}_{4}$ for $1 \mathrm{~h}$, washed in distilled water, dehydrated in graded ethanol series, and embedded in Epon 812 (TAAB, England) before being examined in an Elmiskop 100C (Jeol, Tokyo) operating at $80 \mathrm{kV}$. The peroxidase activity was detected as strongly electron-dense deposits. Control material was incubated in the medium (i) in the absence of $\mathrm{H}_{2} \mathrm{O}_{2}$ or (ii) containing $0.05 \mathrm{M}$ 3-amino-1,2,4-triazole (AT) in order to inhibit catalase if present; if this last treatment fails to reduce staining, peroxidase is assumed to be involved.

\section{Histochemical localization of hydrogen peroxide.}

Small fragments were collected 2, 4, and $6 \mathrm{~h}$ postinoculation from infected or healthy cotyledons of both cultivars. They were incubated $2 \mathrm{~h}$ in one of the following media: (i) $5 \mathrm{mM} \mathrm{CeCl}_{3}$ in $0.05 \mathrm{M}$ Tris-maleate buffer $\mathrm{pH}$; (ii) $\mathrm{CeCl}_{3}$ solution containing $0.02 \mathrm{M}$ aminotriazole in order to inhibit catalase; or (iii) Tris-maleate buffer $\mathrm{pH} 5$ alone (Czaninski et al. 1993). After being washed with buffer, samples were fixed, dehydrated, and embedded in Epon 812. Semi-thin sections $(1.5 \mu \mathrm{m})$ were examined with a Leitz Diaplan microscope (Leitz, Paris) with epipolarized fluorescence light (Liu et al. 1995). Refractive particles of cerium perhydroxide deposits appeared fluorescent when observed with the polarization filter block.

\section{Chemical and reagents.}

2,4-DCP, 3-amino-9-ethylcarbazol, 3-amino-1,2,4-triazole, $\mathrm{BSA}$, bovine heart cytochrome $\mathrm{c}, \mathrm{CeCl}_{3}$, digitonin, DFO, DPI, glutaraldehyde, NADH, SHAM, SOD, and thymol were purchased from Sigma (St. Louis, MO). KCN was purchased from Merck (Damstadt, Germany). Chelex-100 resin and sodium dodecyl sulfate-polyacrylamide gel electrophoresis (SDS-PAGE) molecular weight standards were purchased from Bio-Rad. Ampholytes and protein test substances for $\mathrm{pI}$ determination were purchased from Serva-Boehringer (Ingelheim Bioproducts, Heidelberg, Germany). Epon 812 resin was purchased from J. Delville (St. Germain-en-Laye, France).

\section{ACKNOWLEDGMENTS}

We kindly acknowledge R. Ranjeva (Université P. Sabatier, Toulouse, France) and J. P. Blein (INRA, Dijon, France) for critical reading of the manuscript, J. Mansfield (Wye College, UK) for helpful discussion and English revision, and A. M. Catesson (Université Paris VI, France) for helpful comments on peroxidase cytochemistry.

\section{LITERATURE CITED}

Adam, A. L., Bestwick, C. S., Barna, B., and Mansfield, J. W. 1995. Enzymes regulating the accumulation of active oxygen species during the hypersensitive reaction of bean to Pseudomonas syringae pv. phaseolicola. Planta 197:240-249.

Allan, A. C., and Fluhr, R. 1997. Two distinct sources of elicited reactive oxygen species in tobacco epidermal cells. Plant Cell 9:1559-1572.

Anderson, M. D., Chen, Z., and Klessig, D. F. 1998. Possible involvement of lipid peroxidation in salicylic acid-mediated induction of PR1 gene expression. Phytochemistry 47:555-566.

Apostol, I., Heinstein, P. F., and Low, P. S. 1989. Rapid stimulation of an oxidative burst during elicitation of cultured plant cells. Plant Physiol. 90:109-116.

Auh, C. K., and Murphy, T. M. 1995. Plasma membrane redox enzyme is involved in the synthesis of $\mathrm{O}_{2}^{-}$and $\mathrm{H}_{2} \mathrm{O}_{2}$ by Phytophthora elicitorstimulated rose cells. Plant Physiol. 107:1241-1247.

Baker, C. J., and Orlandi, E. W. 1995. Active oxygen in plant pathogenesis. Annu. Rev. Phytopathol. 33:299-321.

Bestwick, C. S., Brown, I. R., Bennet, M. H. R., and Mansfield, J. W. 1997. Localization of hydrogen peroxide accumulation during the hypersensitive reaction of lettuce cells to Pseudomonas syringae pv. phaseolicola. Plant Cell 9:209-211.

Bolwell, G. P., Butt, V. S., Davies, D. I., and Zimmerlin, A. 1995. The origin of the oxidative burst in plants. Free Radical Res. 11:517-532.

Bolwell, G. P., and Wojtaszeck, P. 1997. Mechanisms for the generation of reactive oxygen species in plant defence - a broad perspective. Physiol. Mol. Plant Pathol. 51:347-366.

Bradford, M. M. 1976. A rapid and sensitive method for quantitation of microgram quantities of protein utilizing the principle of protein-dye binding. Anal. Biochem. 72:248-254.

Czaninski, Y., Sachot, R. M., and Catesson, A. M. 1993. Cytochemical localization of hydrogen peroxide in lignifying cell walls. Ann. Bot. 72:547-550.

Dai, G. H., Nicole, M., Martinez, C., Bresson, E., Daniel, J. F., Andary, C., and Geiger, J. P. 1996. Flavonoids accumulate in cell walls, middle lamellae and callose-rich papillae during an incompatible interaction between Xanthomonas campestris pv. malvacearum race 18 and cotton. Physiol. Mol. Plant Pathol. 49:285-306.

Dangl, J. L., Dietrich, R. A., and Richberg, M. H. 1996. Death don't have no mercy: Cell death programs in plant-microbe interactions. 
Plant Cell 8:1793-1807.

De Feyter, R., Yang, Y., and Gabriel, D. W. 1993. Gene-for-gene interactions between cotton $R$ genes and Xanthomonas campestris pv. malvacearum avr genes. Mol. Plant-Microbe Interact. 6:225-237.

Desikan, R., Wood, L. G., Coffey, M. J., and Neill, S. J. 1996. Generation of active oxygen in elicited cells of Arabidopsis thaliana is mediated by a NADPH oxidase-like enzyme. FEBS Lett. 382:231-217.

Doke, N. 1983. Generation of superoxide anion by potato tuber protoplasts during the hypersensitive response to hyphal wall components of Phytophthora infestans and specific inhibition of the reaction by suppressers of hypersensitivity. Physiol. Plant Pathol. 23:359-367.

Doke, N., and Chain, H. B. 1985. Activation of superoxide generation and enhancement of resistance against compatible races of Phytophthora infestans in potato plants treated with digitonin. Physiol. Plant Pathol. 27:323-334.

Doke, N., and Miura, Y. 1995. In vitro activation of NADPH-dependant $\mathrm{O}_{2} \cdot{ }^{-}$generating system in a plasma membrane-rich fraction of potato tuber tissues by treatment with an elicitor from Phytophthora infestans or with digitonin. Physiol. Mol. Plant Pathol. 46:17-28.

Doke, N., Miura, Y., Sanchez, L. M., Park, H., Noritake, T., Yoshiora H., and Kawakita, K. 1996. The oxidative burst protects plants against pathogen attack: Mechanism and role as an emergency signal for plant bio-defence - a review. Gene 179:45-51

Dwyer, S. C., Legendre, L., Low, P. S., and Leto, T. L. 1995. Plant and human neutrophil oxidative burst complexes contain immunological related proteins. Biochem. Biophys. Acta 1289:231-237.

Essenberg, M., and Pierce, M. 1994. Sesquiterpenoid phytoalexins synthesized in cotton leaves and cotyledons during the hypersensitive response to Xanthomonas campestris pv. malvacearum. Pages 183-198 in: Handbook of Phytoalexin Metabolism and Action. M. Daniel and R. P. Purkayastha, eds. Marcel Dekker, Calcutta, India.

Greenberg, J. T., Guo, A., Klessig, D. F., and Ausubel, F. M. 1994. Programmed cell death in plants: A pathogen-triggered response activated coordinately with multiple defense functions. Cell 77:551-563.

Groom, Q. J., Torres, M. A., Fordham-Skelton, P., Hammond-Kosak, K. E., Robinson, N. J., and Jones, J. D. G. 1996. rbohA, a rice homologue of the mammalian gp91phox respiratory burst oxidase gene. Plant J. 10:515-522.

Halliwell, B. 1978. Lignin synthesis: The generation of hydrogen peroxide and superoxide by horseradish peroxidase and its stimulation by manganese (II) and phenols. Planta 140:81-88.

Hammond-Kosak, K. E., and Jones, J. D. G. 1996. Resistance genedependant plant defense responses. Plant Cell 8:1773-1791.

Hillocks, R. J. 1992. Bacterial blight. Pages 39-86 in: Cotton Diseases. R. J. Hillocks, ed. CAB Int., Oxon, UK

Hunter, R. E., Brinkerhoff, L. A., and Bird, L .S. 1968. The development of a set of upland cotton lines for differentiating races of Xanthomonas malvacearum. Phytopathology 58:830-832.

Innes, N. L. 1983. Bacterial blight of cotton. Biol. Rev. 58:157-176.

Jabs, T., Dietrich, R. A., and Dangl, J. L. 1996. Initiation of runaway cell death in an Arabidopsis mutant by extracellular superoxide. Science 273:1853-1856.

Jabs, T., Tschöpe, M., Colling, C., Hahlbrock, K., and Scheel, D. 1997. Elicitor-stimulated ion fluxes and $\mathrm{O}_{2}^{-}$. from the oxidative burst are essential components in triggering defense gene activation and phytoalexin synthesis in parsley. Proc. Nat. Acad. Sci. USA 94:4800-4805.

Keller, T., Damude, H. G., Werner, D., Doerner, P., Dixon, R. A., and Lamb, C. 1998. A plant homolog of the neutrophil NADPH-oxidase gp $91^{\text {phox }}$ subunit gene encodes a plasma membrane protein with $\mathrm{Ca}^{++}$ binding motifs. Plant Cell 10:255-266.

Kiba, A., Miyake, C., Toyoda, K., Ichinose, Y., Yamada, T., and Shiraishi, T. 1997. Superoxide generation in extracts from isolated plant cell walls is regulated by fungal signal molecules. Phytopathology 87:846-852.

Kiefer, F., Simon-Plas, F., Maume, B., and Blein, J. P. 1997. Tobacco cells contain a protein, immunologically related to the neutrophil small $\mathrm{G}$ protein $\mathrm{Rac} 2$, and is involved in elicitor-induced oxidative burst. FEBS Lett. 403:149-153.

Lamb, C., and Dixon, R. A. 1997. The oxidative burst in plant disease resistance. Annu. Rev. Plant Physiol. Plant Mol. Biol. 48:251-275.

Leach, J. E., Young, S. A., Chittoor, J. M., Zhu, W., and White, F. F. 1996. Induction of defense responses in rice. Pages 115-128 in: Molecular Aspects of Pathogenicity and Resistance: Requirement for
Signal Transduction. D. Mills, H. Kunoh, N. T. Keen, and S. Mayama, eds. American Phytopathological Society, St. Paul, MN.

Levine, A., Tehnaken, R., Dixon, R., and Lamb, C. 1994. $\mathrm{H}_{2} \mathrm{O}_{2}$ from the oxidative burst orchestrates the plant hypersensitive disease resistance response. Cell 6:427-437.

Lindner, W. A., Hoffmann, C., and Grisebach, H. 1988. Rapid elicitorinduced chemiluminescence in soybean cell suspension cultures. Phytochemistry 27:2501-2503.

Liu, L., Eriksson, K. E., and Dean, J. F. D. 1995. Localization of hydrogen peroxide production in Pisum sativum L. using epi-polarized microscopy to follow cerium perhydroxide deposition. Plant Physiol. 107: 501-506.

Low, P. S., and Merida, J. R. 1996. The oxidative burst in plant defense: Function and signal transduction. Physiol. Plant. 96:533-542.

Mansfield, J. W., Bennet, M. H. R., Bestwick, C. S., and Woods-Tör, A 1997. Phenotypic expression of gene-for-gene interaction involving fungal and bacterial pathogens: Variation from recognition to response. Pages 265-291 in: The Gene-for-Gene Relationship in PlantParasite Interactions. I. R. Crute, E. B. Holub, and J. J. Burdon, eds CAB Int., Oxon, UK.

Martinez, C., Geiger, J. P., Bresson, E., Daniel, J. F., Dai, G. H., Andary, C., and Nicole, M. 1996. Isoperoxidases are associated with resistance of cotton to Xanthomonas campestris pv. malvacearum. race 18 Pages 327-332 in: Plant Peroxidases: Biochemistry and Physiology. O. Obinger, U. Burner, R. Ebermann, C. Penel, and C. Greppin, eds. University of Agriculture, Vienna, Austria.

Medhy, M. C. 1994. Active oxygen species in plant defense against pathogens. Plant Physiol. 105:467-472.

Milosevic, N., and Sluzarenko, A. J. 1996. Active oxygen metabolism and lignification in the hypersensitive response in bean. Physiol. Mol. Plant Pathol. 49:143-158.

Mittler, R., and Lam, E. 1996. Sacrifice in the face of foes: Pathogeninduced programmed cell death in plants. Trends Microbiol. 4:10-15.

Murphy, T. M., and Auh, C. K. 1996. The superoxide synthases of plasma membrane preparations from cultured rose cells. Plant Physiol. 110:621-629.

Nair, A. R., and Showalter, A. M. 1996. Purification and characterization of a wound-inducible cell wall peroxidase from carrot roots. Biochem. Biophys. Res. Commun. 226:254-260.

Ogawa, K., Kanematsu, S., and Asada, K. 1997. Generation of superoxide anion and localization of $\mathrm{CuZn}$-superoxide dismutase in the vascular tissue of spinach hypocotyls: Their association with lignification. Plant Cell Physiol. 38:1118-1126.

Polle, A., Otter, T., and Seifert, F. 1994. Apoplastic peroxidases and lignification in needles of Norway spruce (Picea abies L.). Plant Physiol. 106:53-60.

Robertson, E. F., Dannelly, H. K., Malloy, P. J., and Reeves, H. C. 1987. Rapid isoelectric focusing in a vertical polyacrylamide minigel system. Anal. Biochem. 167:290-294

Sanders, S. P., Harrison, S. J., Kuppusamy, H. P., Sylvester, J. T., and Zweier, J. L. 1994. A comparative study of EPR spin trapping and cytochrome $\mathrm{C}$ reduction techniques for the measurement of superoxide anions. Free Radical Biol. Med. 16: 753-761.

Segal, A. W., and Abo, A. 1993. The biochemical basis of the NADPH oxidase of phagocytes. Trends Biochem. Sci. 18:43-47.

Simon-Plas, F., Restérucci, C., Milat, M. L. F., Humbert, C., Montillet, J. L., and Blein, J. P. 1997. AOS production in tobacco cells elicited by cryptogein. Plant Cell Environ. 20:1573-1579.

Sutherland, M. W. 1991. The generation of oxygen radicals during host plant responses to infection. Physiol. Mol. Plant Pathol. 39:79-93.

Tenhaken, R., Levine, A., Brisson, L., Dixon, R., and Lamb, C. 1995. Function of the oxidative burst in hypersensitive disease resistance. Proc. Natl. Acad. Sci. USA 92:4158-4163.

Vera-Estrella, R., Blumvald, E., and Higgins, V. 1992. Effect of specific elicitors of Cladosporium fulvum on tomato suspension cells. Evidence for the involvement of active oxygen species. Plant Physiol. 99:1028-1215.

Wojtaszeck, P. 1997. Oxidative burst: An early plant response to pathogen infection. Biochem. J. 322:681-692

Young, S. A., Guo, A., Guikema, J. A., White, F. F., and Leach, J. E. 1995. Rice cationic peroxidase accumulates in xylem vessels during incompatible interaction with Xanthomonas oryzae pv. oryzae. Plant Physiol. 107:1333-1341. 